\title{
Bilateral Complex Regional Pain Syndrome Associated with Lumbar Disc Herniation
}

\author{
Lomber Disk Hernisi ile İlişkili İki Taraflı Kompleks Bölgesel Ağrı Sendromu
}

\author{
Necmettin YILDIZ, ${ }^{1}$ Gonca ÖDEMİ̧ GÜNGEN, ${ }^{1}$ Olga YAYLALI, ${ }^{2}$ Füsun ARDIÇ \\ Departments of ${ }^{1}$ Physical Medicine and Rehabilitation, ${ }^{2}$ Department of Nuclear Medicine \\ Medical Faculty of Pamukkale University, Denizli, Turkey
}

Complex regional pain syndrome (CRPS) is a syndrome characterized by a combination of pain, trophic changes, and vasomotor disturbances. Although the case reports in the literature describing the CRPS secondary to lumbar disc herniation (LDH) are abundant, in these case reports CRPS is diagnosed in only one extremity. Based on the most recent information available, this is the first case of CRPS associated with LDH that developed in bilateral lower extremities and could be successfully treated conservatively. A 49-year-old male patient was admitted to the clinic with complaints of pain and swelling of both feet and ankles, particularly on the left side. The patient had a history of an episode of low back pain radiating down the left leg that had developed two months previously after bending and lifting. Lumbar magnetic resonance imaging showed posterocentrally- and bilateral paramedially-located L5-S1 disc protrusion. One month after the onset of low back pain, painful stiffness and swelling developed in the joints of both ankles and feet, accompanied by edema, hyperhydrosis and allodynia in the dorsum of the left foot. He did not have any history of trauma. The medical history and laboratory investigations were normal. A diagnosis of CRPS in bilateral lower extremities was confirmed by direct foot-ankle radiographs and three-phase bone scintigraphy. A comprehensive conservative treatment program consisting of drug treatment (nonsteroidal anti-inflamatory drugs, gabapentin and calcitonin), physical therapy, and rehabilitation methods consisting of active-passive range of motion exercises to both ankles with gentle stretching, desensitization activities, gait training, application of a hot pack, ultrasound and transcutaneous electrical nerve stimulation to the lumbar region were applied. The patient's symptoms were relieved by these conservative treatments in six weeks. No recurrence occurred after a follow-up of 12 months. CRPS should be considered as a cause of persistently painful and swollen bilateral lower extremities in a patient with LDH. Early, accurate diagnosis should permit initiation of appropriate treatment and increase the success of the treatment.

Key words: Bone scintigraphy; complex regional pain syndrome; lumbar disc herniation.
Kompleks bölgesel ağrı sendromu (KBAS); ağrı, trofik değişiklikler ve vazomotor bozukluklar ile karakterize bir sendromdur. Literatürde, lomber disk hernisine (LDH) sekonder KBAS'ye ait olgu sunumları oldukça sık olmasına karşın, bunlarda yalnızca tek ekstremitede KBAS gelişimi tanısı konulmuştur. Son bilgilerimize göre olgumuz, LDH ile ilişkili olan ve konservatif olarak başarı ile tedavi edilebilen iki taraflı alt ekstremitede KBAS gelişiminin tanımlandığı ilk olgudur. Kırk dokuz yaşında erkek hasta, özellikle solda belirgin olmak üzere, her iki ayak ve ayak bileğinde ağrı ve şişlik yakınması ile kliniğe başvurdu. Hastanın iki ay öncesinde, eğilerek ağır yük kaldırma sonrası sol bacağa yayılan bel ağrısı episodu öyküsü vardı. Lomber manyetik rezonans görüntüleme ile posterosantral ve iki taraflı paramedian yerleşimli L5-S1 disk protrüzyonu saptandı. Bel ağrısının başlangıcından bir ay sonra, sol ayak sırtında allodini, hiperhidrozis ve ödeme ek olarak her iki ayakayak bileği ekleminde şişlik ve ağrılı katılık hali gelişmişti. Hastanın herhangi bir travma öyküsü yoktu. Tıbbi öyküsü ve laboratuvar değerlendirmeleri normaldi. İki taraflı alt ekstremitede KBAS tanısı direkt ayak-ayak bileği grafisi ve üç fazlı kemik sintigrafisi ile doğrulandı. İlaç (non-steroidal antienflamatuvar ilaçlar, gabapentin, kalsitonin) tedavisi, her iki ayak bileğine nazik germe ile birlikte aktif-pasif eklem hareket açıklığı egzersizleri, desensitizasyon aktiviteleri, yürüme eğitimi, lomber bölgeye sıcak torba, transkütanöz elektriksel sinir stimülasyonu ve ultrason uygulamalarını içeren fizik tedavi ve rehabilitasyon yöntemlerinden oluşan kapsamlı bir konservatif tedavi programı uygulandı. Hastanın semptomları bu konservatif tedaviler ile altı haftada hafifledi. On iki aylık takipte tekrarlama gözlenmedi. Lomber disk hernili bir hastada iki taraflı olarak alt ekstremitelerde sürekli ağrı ve şişlik olmasının bir nedeni olarak KBAS akılda tutulmalıdır. Erken ve doğru tanı, uygun tedavinin başlanmasına ve tedavi başarısının artmasına izin verecektir.

Anahtar sözcükler: Kemik sintigrafisi; kompleks bölgesel ağrı sendromu; lomber disk hernisi.

Received: November 2, 2009 Accepted: December 1, 2009

Correspondence: Necmettin Yıldız, M.D. Pamukkale Üniversitesi Tıp Fakültesi Fizik Tedavi ve Rehabilitasyon Anabilim Dalı, 20070 Kınıkı, Denizli, Turkey.

Tel: +90 258 - 4440728 / 4996 e-mail: necmi74tr@hotmail.com

Presented at the $5^{\text {th }}$ World Congress of the International Society of Physical and Rehabilitation Medicine, June 13-17, 2009, Istanbul, Turkey.

O2011 Turkish League Against Rheumatism. All rights reserved. 
Causalgia or complex regional pain syndrome (CRPS)type II is a syndrome formed by a combination of pain, trophic changes and vasomotor disturbances. This syndrome is characterized by pain on active or passive movement, abnormal regulation of blood flow and sweating, and edema of skin and subcutaneous tissues. ${ }^{[1]}$ It is self-limiting in some individuals which results in long-lasting impairment for some and disability in others. ${ }^{[2]}$

Although cases describing CRPS secondary to lumbar disc herniation (LDH) are abundant in the literature, ${ }^{[3-9]}$ CRPS in these reports developed in association with $\mathrm{LDH}$ or after disc surgery in one extremity. To our knowledge, based on our review of the literature, we have not found any case of bilateral CRPS in the lower extremities associated with LDH and hereby present the first such case which was successfully treated conservatively.

\section{CASE REPORT}

A 49-year-old man complained of pain and swelling of the feet and ankles, particularly on the left side. Two months previously, he had experienced an episode of low back pain radiating down the left leg which developed after an episode of bending and lifting. At that time, he was diagnosed with LDH which was confirmed by magnetic resonance (MR) imaging. The lumbar spine MR images showed L5-S1 disc protrusion in the posterocentral region and in bilateral paramedian regions which was more apparent on the right side (Figure 1). His pain decreased after several days of bed rest and analgesic treatment. One month later low back pain, aching and stiffness developed in the joints of both ankles and feet and was accompanied by dorsal hyperalgesia and

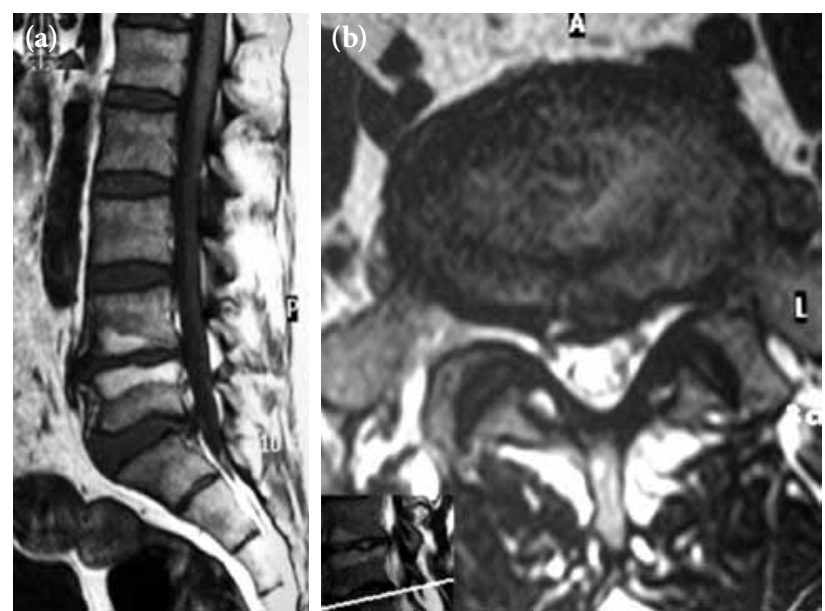

Figure 1. Lomber magnetic resonance images (a) sagittal, (b) axial, L5-S1 posterocentral and bilateral paramedian disc protrusion with predominance on the right side. allodynia of the left foot. The aching was exacerbated by local pressure or attempted foot movement. Over the next month the symptoms steadily worsened to the point of an inability to bear any weight on the right foot. Mild swelling of the feet, edema, and hyperhydrosis of the left foot were also noted. Ankle motion was restricted near the end of range. There was a complaint of low back discomfort. Straight leg raising on the left side was only 45 degrees. There was a suggestion of mild plantar flexor weakness (4/5, 0 to 5 scale) on the left, but extreme pain on palpation of the left lower extremity prevented reliable motor strength and sensorial evaluation. The remainder of the neuromuscular examination was unremarkable. Rectal tone was intact, and pulses were normal. The patient had no history of trauma. Past medical history, family history and a review of systems were unremarkable revealing no indication of endocrine, rheumatologic or other systemic diseases.

Routine laboratory investigations disclosed no abnormalities. Electromyography disclosed involvement of the left S1 root (gastrocnemius muscle had $2+$ waves with mild decreased motor unit numbers) and corresponding paraspinal muscles suggestive of preganglionic damage; sensory and motor conduction was normal. Foot radiographs showed a pattern of osteopenia consistent with left CRPS (Figure 2). Technetium-99m methylene diphosphonate (Tc-99m MDP) three-phase bone scintigraphy (TPBS) confirmed the clinical diagnosis of bilateral CRPS by detecting the mild or intense increased activity uptake in a dynamic, early blood pool, especially in delayed static images (Figure 3).

Comprehensive conservative therapy was commenced consisting of drug treatment (non steroidal anti-inflammatory drug [NSAID], gabapentin and calcitonin nasal spray), an outpatient rehabilitation program involving active and passive range of motion to both ankles with gentle stretching, desensitization activities (including contrast baths), gait training, and a physical therapy program involving hot packs, ultrasound and TENS to the lumbar region. Three weeks later, the back pain was totally relieved and lower extremity symptoms were mainly relieved in six weeks. There was no residual foot stiffness, swelling, edema or any atrophic changes. Electromyography six months after therapy showed a decrease in denervation. No recurrence occurred after a follow-up of 12 months.

\section{DISCUSSION}

Causalgia or complex regional pain syndrome is a painful syndrome affecting one or more extremities of 


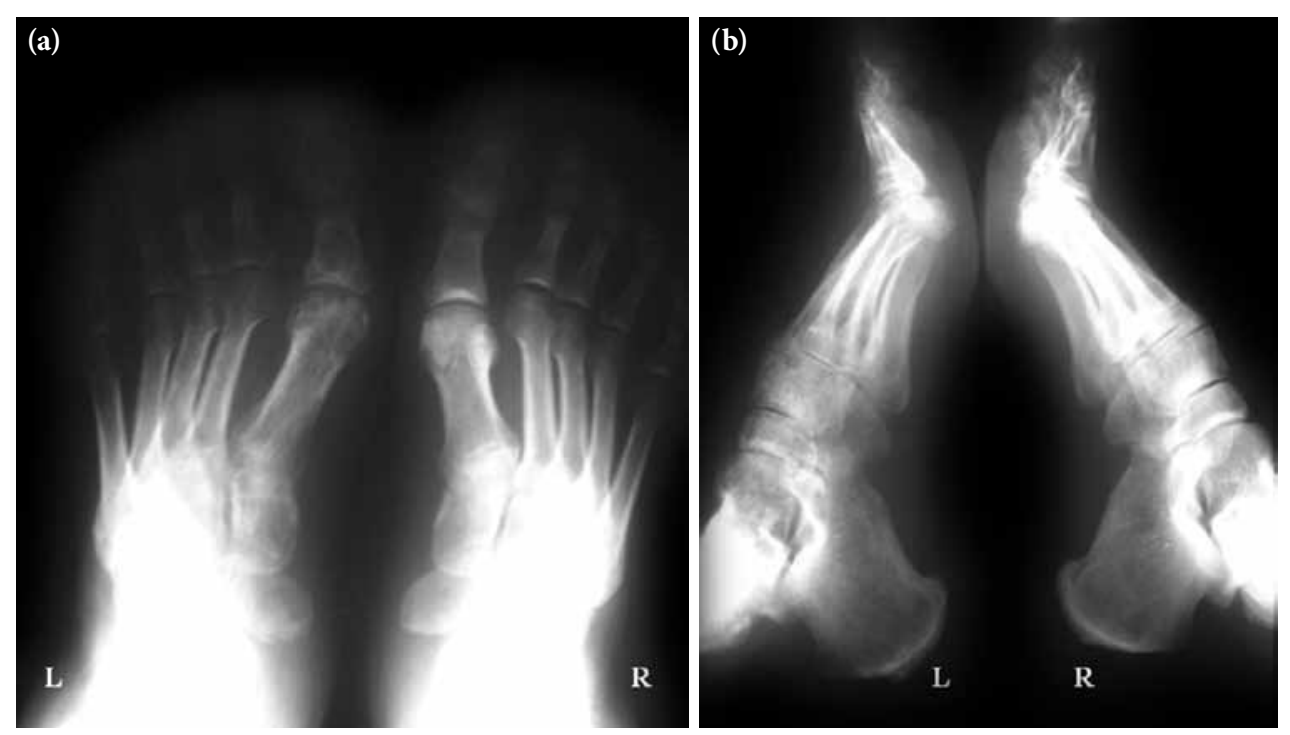

Figure 2. Bilateral ankle-foot radiograph: (a) anterior and (b) lateral views of the left foot show periarticular demineralization of the phalanges and tarsal bones. Right foot appears normal.

the body and is marked by a wide variety of symptoms. ${ }^{[10]}$ Jinkins et al. ${ }^{[1]}$ proposed an anatomic basis for a link between CRPS and disc herniation. The complex neural interconnections between somatic and autonomic nervous systems account for the nonspecific pain and referred autonomic dysfunction that may be represented in the form of abnormal vasomotor, pilomotor and sudomotor activity occasionally associated with $\mathrm{LDH} .{ }^{[9,11]}$

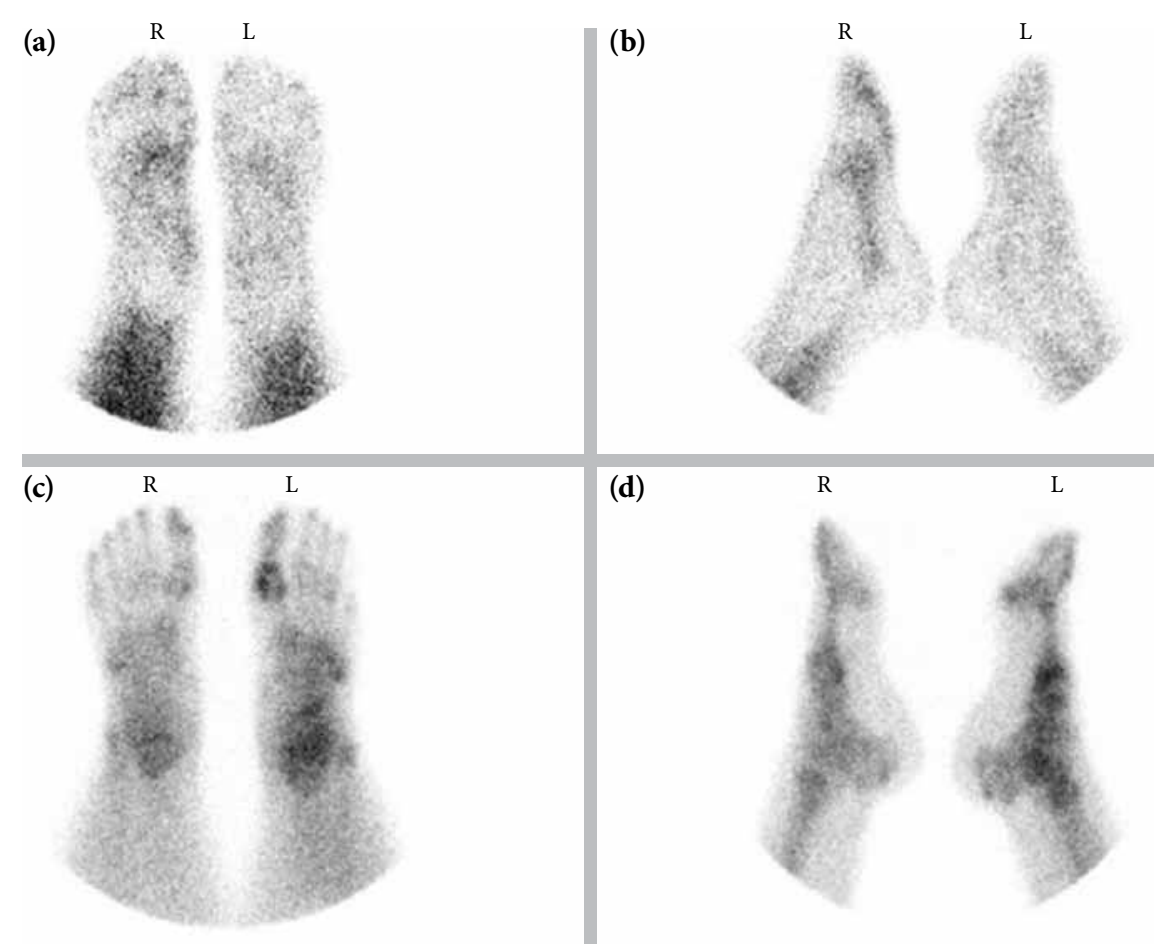

Figure 3. The Tc-99m MDP three-phase bone scintigraphy demonstrating view accordance with bilateral CRPS, particularly severe in the left side. $(\mathbf{a}, \mathbf{b})$ On the three-phase bone scintigraphy, the blood pool images show hyperemia of the bilateral metatarsophalangeal joint and tibia. The hyperemia is particularly intense in the right side. (c, d) Delayed static images show bilateral diffuse increased activity uptake in the $1^{\text {st }}$ phalanx, in metatarsophalangeal joint and ankle joint, more intensely on the left side. 
The pathogenesis of CRPS evolves from disturbances in both the peripheral and central nervous systems. Interest has recently increased in the role of inflammatory responses in the initial phase of the disorder. Inflammatory signs such as swelling, redness, warmth and pain are common features in the early stage of CRPS. In addition to classic inflammation, neurogenic inflammation has been demonstrated in CRPS. Neurogenic inflammation resembles classic inflammation but is initiated by neuropeptides instead of lymphocytes and cytokines. ${ }^{[10,12]}$

Causalgia or complex regional pain syndrome is usually described after a specific initiating event (in most cases trauma or an operation), but it is sporadically observed after a stroke, myocardial infarction and infection. ${ }^{[13]}$ The CRPS-type II which develops after a nerve lesion is by definition a neuropathic pain syndrome. ${ }^{[1]}$ Although the actual incidence of CRPStype II is unknown, it is estimated to occur in at least $1 \%$ to $5 \%$ of patients who have incurred a peripheral nerve injury. ${ }^{[2]}$

This entity is common in the limbs and is characterized by pain (spontaneous pain, hyperalgesia, allodynia), active and passive movement disorders, abnormal regulation of blood flow and sweating, edema of skin and subcutaneous tissues, and trophic changes of skin, organs of skin and subcutaneous tissues. ${ }^{[1]}$ Upper extremity CRPS-type II is most frequently caused by injury to the brachial plexus or median nerve. Lower extremity CRPS-type II is typically caused by injury to the sciatic or tibial nerve. ${ }^{[2]}$ In the literature, CRPS secondary to LDH is common and occurred in only one extremity. ${ }^{[3-9]}$ Some of the reported cases are secondary to $\mathrm{LDH},{ }^{[3,4,7-9]}$ and others are secondary to operated LDH. ${ }^{[3,5,6]}$ Except for a single case of CRPS treated with sympathetic block, ${ }^{[8]}$ all other reported CRPS cases regressed symptomatically after surgical treatment of herniation. ${ }^{[3,4,7,9]}$ We report the only case of bilateral CRPS in the lower extremities due to $\mathrm{LDH}$ that was treated conservatively. One explanation for CRPS being bilateral in our case could be the presence of bilateral lumbar disc protrusion with right-sided predominance which clinically presented itself with pain radiating to the left leg. The other explanation could be immobilization of both legs during the bed rest period.

The characteristic appearance of the roentgenogram in CRPS is that of extensive mottled demineralization. The TPBS is valuable, particularly in mild or early cases of CRPS where roentgenograms of the extremities may be negative. ${ }^{[3]}$ In our case, direct radiography showed the characteristic appearance only on the left foot, but the right foot appeared normal. In the early period when the right foot appeared normal on radiographs, the bilateral occurrence of CRPS was detected by the TPBS showing the mild or intense increased activity uptake in a dynamic, early blood pool, especially in delayed static images. ${ }^{[3,14]}$ While symptoms of CRPS associated with $\mathrm{LDH}$ in the literature either begin or subside with a disc operation, ${ }^{[3-7,9]}$ conservative measures relieved both the LDH and the CRPS in our case. The symptoms in our case resolved with medical therapy consisting of NSAIDs, calcitonin and gabapentin in addition to a rehabilitation program including exercise and physical therapy.

The treatment of CRPS-type II is most successful when performed early in the course of the syndrome, preferably within three months after onset. Early diagnosis is therefore crucial. ${ }^{[2]} \mathrm{A}$ delay in diagnosis and/or treatment for this syndrome can result in severe physical and psychological problems. ${ }^{[15]}$ We propose that early diagnosis (aided by TPBS) of CRPS in our case (one month after the onset of symptoms) added to the success of conservative treatment.

Causalgia or complex regional pain syndrome is a challenging pain syndrome which can be severe and functionally debilitating. It should be considered as a cause of bilateral, persistently painful and swollen extremities in a patient with LDH. Early, accurate diagnosis permits initiation of appropriate therapeutic interventions and enhances the potential for successful treatment.

\section{Declaration of conflicting interests}

The authors declared no conflicts of interest with respect to the authorship and/or publication of this article.

\section{Funding}

The authors received no financial support for the research and/or authorship of this article.

\section{REFERENCES}

1. Jänig W, Baron R. Complex regional pain syndrome: mystery explained? Lancet Neurol 2003;2:687-97.

2. Bryant PR, Kim CT, Millan R. The rehabilitation of causalgia (complex regional pain syndrome-type II). Phys Med Rehabil Clin N Am 2002;13:137-57.

3. Carlson DH, Simon H, Wegner W. Bone scanning and diagnosis of reflex sympathetic dystrophy secondary to herniated lumbar disks. Neurology 1977;27:791-3. 
4. Ballard EM, Ellenberg M, Chodoroff G. Reflex sympathetic dystrophy syndrome secondary to L5 radiculopathy. Arch Phys Med Rehabil 1991;72:595-7.

5. Chodoroff B, Ball RD. Lumbosacral radiculopathy, reflex sympathetic dystrophy and tarsal tunnel syndrome: an unusual presentation. Arch Phys Med Rehabil 1985;66:185-7.

6. Sachs BL, Zindrick MR, Beasley RD. Reflex sympathetic dystrophy after operative procedures on the lumbar spine. J Bone Joint Surg [Am] 1993;75:721-5.

7. Condon F, Kenny PJ, Griffin JG, O’Rourke K. Reflex sympathetic dystrophy associated with extraforaminal disc herniation at the L5-S1 level. J Spinal Disord 1998; 11:448-51.

8. Adachi M, Tamaoka A, Harada K, Mizusawa H, Shoji S. Reflex sympathetic dystrophy secondary to lumbar disk herniation. Rinsho Shinkeigaku 1994;34:61-4. [Abstract]

9. Bernini PM, Simeone FA. Reflex sympathetic dystrophy associated with low lumbar disc herniation. Spine (Phila Pa 1976) 1981;6:180-4.
10. Hettne KM, de Mos M, de Bruijn AG, Weeber M, Boyer S, van Mulligen EM, et al. Applied information retrieval and multidisciplinary research: new mechanistic hypotheses in complex regional pain syndrome. J Biomed Discov Collab 2007;2:2.

11. Jinkins JR, Whittemore AR, Bradley WG. The anatomic basis of vertebrogenic pain and the autonomic syndrome associated with lumbar disk extrusion. AJR Am J Roentgenol 1989;152:1277-89.

12. Leis S, Weber M, Schmelz M, Birklein F. Facilitated neurogenic inflammation in unaffected limbs of patients with complex regional pain syndrome. Neurosci Lett 2004; 359:163-6.

13. Merritt WH. The challenge to manage reflex sympathetic dystrophy/complex regional pain syndrome. Clin Plast Surg 2005;32:575-604.

14. Sintzoff S, Sintzoff S Jr, Stallenberg B, Matos C. Imaging in reflex sympathetic dystrophy. Hand Clin 1997;13:431-42.

15. Seale KS. Reflex sympathetic dystrophy of the lower extremity. Clin Orthop Relat Res 1989;243:80-5. 